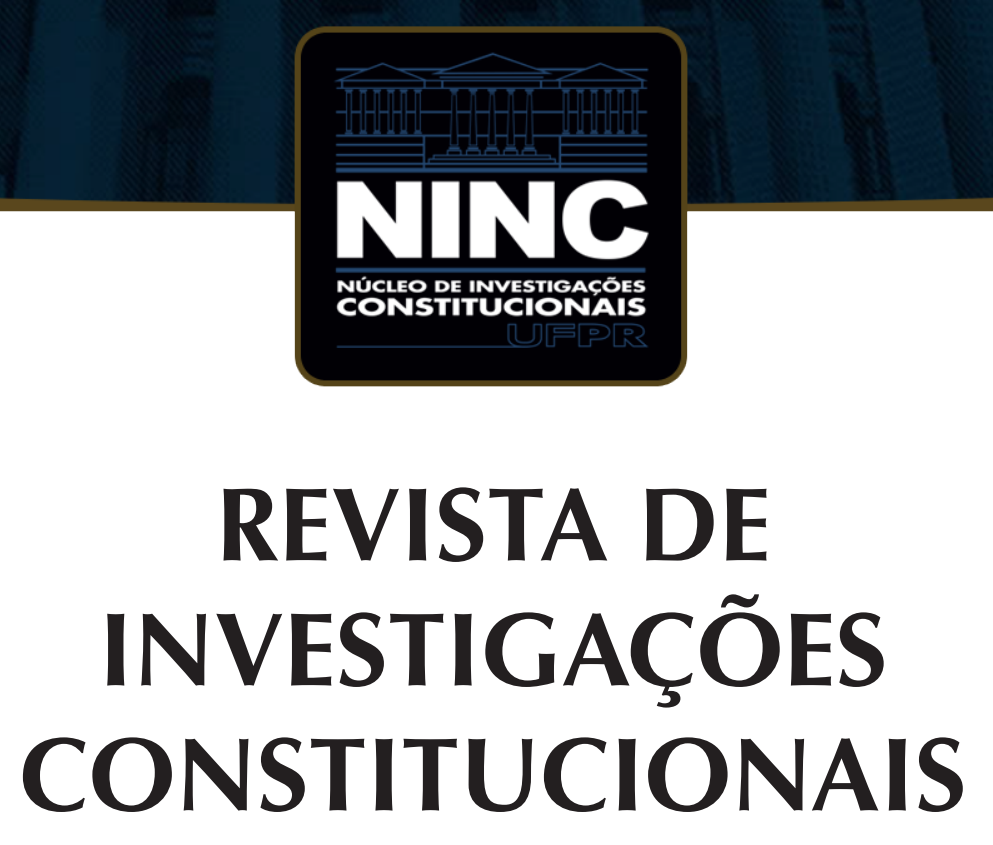

JOURNAL OF CONSTITUTIONAL RESEARCH

vol. 6 | n. 3 | setembro/dezembro 2019 | ISSN 2359-5639 | Periodicidade quadrimestral Curitiba | Núcleo de Investigações Constitucionais da UFPR | www.ninc.com.br 


\title{
Legal pluralism: an approach from the new Latin American constitutionalism and the jury of the indigenous court
}

\section{Pluralismo jurídico: Uma abordagem a partir do novo constitucionalismo latino-americano e do tribunal do júri indígena}

\author{
GIULIA PAROLA ${ }^{\text {l, * }}$ \\ 'Universidade Federal Fluminense (Niterói-RJ, Brasil) \\ giuliaparola.law@gmail.com \\ https://orcid.org/0000-0001-8107-5765 \\ THAIANA CONRADO NOGUEIRA ${ }^{1, * *}$ \\ ' Universidade Federal Fluminense (Niterói-RJ, Brasil) \\ thaiananogueira@yahoo.com.br \\ https://orcid.org/0000-0003-1781-5612
}

\section{THOMAZ MUYLAERT DE CARVALHO BRITTO ",***}

" Universidade Estácio de Sá (Rio de Janeiro-RJ, Brasil) thomazbritto@hotmail.com https://orcid.org/0000-0002-8217-7947

Recebido/Received: $07.10 .2019 /$ October $7^{\text {th }}, 2019$ Aprovado/Approved: $18.11 .2019 /$ November $18^{\text {th }}, 2019$

Abstract

Through the presented article we seek to analyze the way Indigenous Peoples insert themselves in the context of the new Latin American constitutionalism, with a special
Resumo

Por meio do presente artigo, busca-se fazer uma análise, ainda que sucinta, da forma como os indígenas se inserem no contexto do novo constitucionalismo latino-americano,

Como citar esse artigo/How to cite this article: PAROLA, Giulia; NOGUEIRA, Thaiana Conrado; BRITTO, Thomaz Muylaert de Carvalho. Legal pluralism: an approach from the new Latin American constitutionalism and the jury of the indigenous court. Revista de Investigações Constitucionais, Curitiba, vol. 6, n. 3, p. 621-645, set./dez. 2019. DOI: 10.5380/rinc.v6i3.69579.

* Professor in Environmental Law and Post-doc Researcher Scholar, Master in Constitutional Law in South America, Universidade Federal Fluminense (Niterói-RJ, Brazil). PhD in Environmental Law in the University of Paris V (France). LLM in the University of Iceland in International Environmental Law. Bachelor of Law, Università degli Studi di Torino (Italy). E-mail: giuliaparola.law@ gmail.com

** Masters student in Constitutional Law at the Universidade Federal Fluminense (Niterói-RJ, Brazil). Graduated student in Constitucional Law, Universidade Cândido Mendes (Niterói, Rio de Janeiro, Brazil). Bachelor of Law, Universidade Federal Fluminense (Niterói, Rio de Janeiro, Brazil). Assistant Editor of the Journal “Culturas Jurídicas", Universidade Federal Fluminense (Niterói, Rio de Janeiro, Brazil). E-mail: thaiananogueira@yahoo.com.br.

*** Professor of Constitutional Law at Universidade Estácio de Sá (Rio de Janeiro-RJ, Brazil). Masters in Constitutional Law at the Universidade Federal Fluminense (Niterói-RJ, Brazil). Postgraduate lato sensu in Constitutional Law from Universidade Cândido Mendes (Brazil). Bachelor of Law at Universidade Federal Fluminense. E-mail: thomazbritto@hotmail.com. 
focus on the aspect of the legal pluralism and on the way the Indigenous Peoples act towards the Judiciary. For that, the paradigmatic cases of the Ecuadorian, Bolivian and also the Brazilian constitutions are analyzed. From there, we go to the concrete cases, where factual situations are verified, at least in theory, where the natives had an active participation in the judiciary criminal process in Brazil. The main goal of this article is to scrutinize how those cases configure what denominates as legal pluralism and in what standards the Brazil differentiates from the other Latin American countries on the legal custody of the indigenous rights and the recognition and respect of «the other», here understood as a native.

Keywords: legal pluralism; new latin american constitutionalism; indigenous rights; indigenous jury; Brazil. com enfoque especial no aspecto do pluralismo jurídico e na forma como os indígenas atuam perante o Poder Judiciário. Para tanto, são analisados os casos paradigmáticos das Constituições equatoriana e boliviana, e também da Constituição brasileira. A partir do estudo desses diplomas, passa-se aos casos concretos, em que são verificadas situações fáticas onde, ao menos em tese, os indígenas tiveram uma participação ativa em processos judiciais criminais no Brasil. O objetivo primordial do artigo é justamente verificar em que medida esses casos configuram o que se denomina pluralismo jurídico e em que medida o Brasil se diferencia dos demais países latino-americanos no que tange à tutela judicial dos direitos indígenas e ao reconhecimento e respeito do "outro", aqui compreendido como o indígena.

Palavras-chave: pluralismo jurídico; novo constitucionalismo latino-americano; direitos indígenas; juri indígena; Brasil.

\section{CONTENTS}

1. Introduction; 2. New Latin American Constitutionalism; 2.1. Brazilian Federal Constitution from 1988; 2.2. Equatorial Constitution from 2008; 2.3. Bolivian Constitution from 2009; 2.4. The Problem of (In) Effectiveness of the Constitutional Commandment; 3. Legal Pluralism; 3.1. The Indigenous Jury in Brazil; 4. Conclusion; 5. References.

\section{INTRODUCTION}

The indigenous school was historically decimated and subdued. Seen by settlers as inferior, they were expelled from their lands, separated from their families, violated and even subjected to forced labor. This was a reality that marked the emergence of what is now called Latin America. There are various countries, mainly colonized by Spaniards, with the exception of Brazil, whose histories have been tainted by indigenous blood. ${ }^{1}$

Today, years after the arrival of the first European vessels at the American continent, the natives remain marginalized from mainstream society. Indeed, there have been many efforts to recognize rights to Indigenous Peoples and what is termed as the new Latin American constitutionalism was the main reason for this. At the end of the 1990s, a process of amendments of the Latin American Constitutions began, triggered especially by the end of authoritarian regimes in those countries, like Brazil and Bolivia, for instance. One of the main consequences of this process was the introduction of the indigenous in the constitutional texts, as subject and not as object of rights. In

\footnotetext{
1 ARAUJO JR., Julio José. Direitos territoriais indígenas: uma interpretação intercultural. Rio de Janeiro: Processo, 2018, p. 74.
} 
this context, the Ecuadorian Constitution of 2008 and the Bolivian Constitution of 2009 were highlighted. ${ }^{2}$

However, despite these efforts, indigenous communities are not protected by the State in the way they should. This is because there is a profound practical difficulty in conferring effectiveness on the constitutional commandments, especially because the power's structure.

The natives are able to physically speak, but, at the same time, they are seen as subaltern, who cannot express themselves without the intervention of others, which reproduces structures of oppression and keeps them in silence. ${ }^{3}$ It is, basically, the silencing of the other by recognizing their inability to express his own opinions, that is, by the - mistaken - realization of the intellectual incapacity of the native to recognize what is right and wrong within society.

In this context, the legal space was characterized as a mechanism of oppression and silencing. The Law can be used - and often is - as an instrument of colonial domination, imposition of standards, marginalization of the "other one", the different, that does not fit into the European social standards of behavior. In the case of indigenous communities, these have been removed from the legal spectrum. Although the new Latin American constitutionalism recognized rights to them, this was not enough.

For all that is stated above, it is essential that there is a transformation in the political-juridical structure in Latin America, so as to concretely insert native people, respecting their traditions and cultures and allowing the system to adapt to their specificities and concrete needs.

It is under this bias that this article is inserted, whose primary objective is to analyse, without pretending to be exhaustive, the Brazilian, Ecuadorian and Bolivian Constitutions, verifying how their commandments are executed in practical reality, so that it is then possible to glimpse forms of legal pluralism ${ }^{4}$ which allow Indigenous peoples' consultation without the need of intermediaries.

Thus, the first chapter objective is to contextualize what is called the new Latin American constitutionalism and to study the Brazilian Constitution of 1988, in order to elucidate how the native is treated in the country, and the more recent Ecuadorian and Bolivian Constitutions, which are highlighted by the extensive list of rights granted to indigenous communities. Subsequently, it discusses how effectively these rights are conferred. Finally, the focus becomes the legal pluralism as a way of respecting and

\footnotetext{
2 ARAUJO JR., Julio José. Direitos territoriais indígenas: uma interpretação intercultural. Rio de Janeiro: Processo, 2018, p. 91.

3 ARAUJO JR., Julio José. Direitos territoriais indígenas: uma interpretação intercultural. Rio de Janeiro: Processo, 2018, p. 63.

$4 \quad$ The legal pluralism is, roughly speaking, a possibility of coexistence of more than one legal system at the space and at the same time. For the purposes of this article, it can be understood as a coexistence of the common legal system and the indigenous legal system. It opposes the legal monism, based on the idea of oneness.
} 
adapting the system to the natives. At that moment an actual case is analysed in which there was participation of tribes in a criminal process in Brazil.

To this end, a legal-normative research part will be adopted, through a documentary and bibliographical research source. The method of research employed is logical-deductive reasoning.

\section{NEW LATIN AMERICAN CONSTITUTIONALISM}

The new Latin American constitutionalism was inaugurated with the promulgation of several new Constitutions in the countries of the region, such as Brazil (1988), Mexico (1992) and Paraguay (1992), which brought many advances, especially in social aspects and inclusion of minorities. The cultural diversity influenced several Constitutions promulgated in the Latin American continent. According to Araujo "The debate on multiculturalism and the strengthening of new social movements, (...) were incorporated into constitutional texts through the constitutional recognition of pluralism in their respective societies and the establishment of guidelines related to the fight against inequalities and the appreciation of different forms of life ${ }^{\prime \prime 5}$. The texts that emerged from this process included new pluralistic and intercultural approach.

Raquel Z. Yrigoyen Fajardo, ${ }^{6}$ exponent on the subject, subdivides the process of Latin American constitutional transformation into three different cycles, namely:

Multicultural (1982 - 1988): at that moment there was the initial recognition of multiculturalism, with the attendance of some basic indigenous demands. It includes the Brazilian Constitution of 1988, for example;

Pluricultural (1989-2005): it was marked by the replacement of the multicultural perspective by the pluricultural one, ${ }^{7}$ in which the recognition of indigenous rights deepened. Rights arose, such as identity, languages, bilingual education, etc. The main innovation, however, came from the recognition of legal pluralism, although incipient.

\footnotetext{
5 ARAUJO JR., Julio José. Direitos territoriais indígenas: uma interpretação intercultural. Rio de Janeiro: Processo, 2018, p. 91.

6 FAJARDO, Raquel Z. Yrigoyen. Pluralismo jurídico y jurisdicción indígena en el horizonte del constitucionalismo pluralista. In: BALDI, Cesar Augusto (Coord.). Aprender desde o sul: novas constitucionalidades, pluralismo jurídico e plurinacionalidade. Belo Horizonte: Fórum, 2015, p. 35.

7 About the subject, it is worth noting the lessons of ARAUJO JR., Julio José. Direitos territoriais indígenas: uma interpretação intercultural. Rio de Janeiro: Processo, 2018, p. 118: "The doctrines of multiculturalism - especially its more official aspects - do not meet the demands of the subaltern peoples who live the coloniality of the power, especially from ethnic groups (...) It is common for multiculturalism to think of difference as a data to be accommodated, recognized and isolated ... The dangerous of essentialisms lies in the requirement of a distinct and pure act (language, clothing, practices, religion), whose absence entails the questioning of identity (...) The multiculturalism also fails to give due the correct value to the historicity and depth of the colonial wound (...) In the legal system, the first step is to remove the hierarchy of knowledge and reject an interpretation based on a single world view. The respect for legal pluralism is an important task, and the projects of the new Latin American constitutionalism will emphasize it.."
} 
Included in this cycle, for example, are the Mexican (1992), Paraguayan (1992), and Peruvian (1993) Constitutions;

Plurinational (2006 - 2009): This is the most radical phase of the three, in which there were very significant structural changes. Countries that adopted Constitutions at that time recognized that Indigenous Peoples are original nations, collective subjects of rights, with autonomy and self-government. In this context came ideas such as the good life ousumak kawsay and pachamama. Classical examples of constitutions promulgated in this period are Ecuadorian (2008) and Bolivian (2009). It is noteworthy that in these two countries a large part of the population declares themselves to be native, which certainly had relevance in determining these new policies.

As far as indigenous communities are concerned, these three cycles have brought about very significant transformations, especially with regard to the recognition of Indigenous Law, so that it is possible to say that the new Latin American constitutionalism inaugurated a new moment for these peoples, progressively removing them from obscurity and making them subjects of constitutionally assured rights.

\subsection{Brazilian Federal Constitution from 1988}

As seen earlier, the 1988 Constitution $^{8}$ is part of the first cycle of constitutional changes and ruptures that Latin America has undergone in recent years. Of all the phases, this was the most "timid", most probably because it was the first step towards the insertion of Indigenous Peoples in the constitutional text. ${ }^{9}$

Although not as grandiose as the later Constitutions, enacted in neighboring countries, the 1988 Constitution brought with it great victories for indigenous communities. This meant that, at that moment, the small advances that had taken place meant a break with the previous policy, which for years had silenced and subjugated the natives.

A factor that contributed decisively to the recognition of indigenous rights in the constitutional text was the intense participation of indigenous communities and leaders in the process of creating the Constitution. The presence and effective participation of the natives in the National Constituent Assembly meant for them the recognition of their existence and their autonomy, as well as overcoming the idea that they were irrational, wild animals incapable of determining their own future. ${ }^{10}$ To then were

8 BRASIL. Constituição da República Federativa do Brasil de 1988. Available at: <http://www.planalto. gov.br/ccivil_03/constituicao/constituicaocompilado.htm>. Last access: 22 Aug. 2018.

$9 \quad$ FAJARDO, Raquel Z. Yrigoyen. Pluralismo jurídico, derecho indígena y jurisdicion especial en los países andinos. El otro Derecho, ISLA, Bogotá, n. 30, p. 182-184, jun. 2004. Available at: <https://www.cejamericas. org/Documentos/DocumentosIDRC/128elotrdr030-06.pdf>. Last access: 15 Dec. 2018, p. 35.

10 LACERDA, Rosane. Os povos indígenas e a Constituinte: 1987 - 1988. Brasília: Conselho Indigenista Missionário, 2008, p. 141. 
given the word and the power to decide jointly with others on the directions of public policies that concerned their communities and ethnicities.

Chapter VIII of Title VIII of the Major Charter specifically covers indigenous communities and, essentially, deals with the recognition of certain rights. This represents a very great transformation, since no other national constitution had dealt with the subject in this way, dedicating a whole chapter to it. The caput of article 231 of the Constitution, for example, advocates that "Indigenous Peoples are recognized for their social organization, behaviours, languages, beliefs and traditions, and the original rights to the lands they traditionally occupy, and it is up to the Union to demarcate, protect and enforce all their property".

The referenced article "is acclaimed by all for the constitutional innovation of considering indigenous lands accrue from an original right, which means that it precedes the arrival of the Portuguese".11

Despite all this, there is still a long way to go in Brazil. As stated earlier, the 1988 Constitution brought transformations, but not so deep. In this sense, the new Constitution has advanced on the indigenous issue but the text "has not yet exorcised the specter of marginalization that sometimes serves by the euphemism of "emancipation"12. According to Alcida Rita Ramos"for the first time in the country's history, (Brazil) assumes that being a native is a legitimate state and not a temporary condition. But (...) The natives are still protected, they still have their rights limited, even if they give all the demonstrations of civic knowledge and resourcefulness in the national life."13.

It apprehends, from this, a problematization referent to the full citizenship of the natives. There were, indeed, advances with the advent of the 1988 Constitution, but there are still many rights to be recognized and, above all, made effective. In addition, the territorial rights approach in the Constitution of 1988, is interpreted as the dictatorial period were still in force. The Raposa Serra do Sol Case is the most famous example where the Federal Supreme Court (STF) adopted the so-called "time frame" by requiring the physical presence of the natives on their lands in 5 of October 1988. The STF in this manner "naturalized the relations of domination to which the natives were subject in the previous constitutional order"14. The impacts of this interpretation "on the ethnic assertion and territorial claims of the present, (...) received distrustful treatment, which regards the growth of the indigenous population as a fraudulent practice. Additionally,

\footnotetext{
11 GOMES, Mércio Pereira. Os índios e o Brasil. São Paulo: Contexto, 2012, p. 111.

12 RAMOS, A. Os direitos do índio no Brasil: na encruzilhada da cidadania. Série Antropologia. vol. 116, Brasília: DAN/UnB, 1992. Available at: <http://dan.unb.br/images/doc/Serie116empdf.pdf>, p. 5-6.

13 RAMOS, A. Os direitos do índio no Brasil: na encruzilhada da cidadania. Série Antropologia. vol. 116, Brasília: DAN/UnB, 1992. Available at: <http://dan.unb.br/images/doc/Serie116empdf.pdf>, p. 5-6.

14 ARAUJO JR., Julio José. Direitos territoriais indígenas: uma interpretação intercultural. Rio de Janeiro: Processo, 2018, p. 5.
} 
the law remains very attached to a uniform treatment of these groups, paying little attention to their specificities, their knowledge and legal pluralism"15. The advance made by the Constitution is rapidly stopped by using, according to Araujo, "pre-established hegemonic models. The internal and external conflicts involving these groups are usually analyzed from the viewpoint of the surrounding society, which abstractly selects the priority legal assets (such as national security and private property), relegating territorial rights to a lesser extent".16

In this way, the constant distrust of the Federal Supreme Court has affected the very recognition of indigenous rights after the enactment of the Constitution. There are still many steps to be taken in Brazil, with the purpose of consolidating the rights guaranteed by the Constitution to the natives. Their territorial rights, as has been observed, continue on the verge of being violated.

It is known that there was, in fact, a constitutional provision regarding the fundamental rights of indigenous groups. However, the consolidation of these rights is a deficiency of the State, which has not subsidized efforts to effectively protect the rights of these groups. Thus, indigenous justice can be a measure to be adopted in Brazil, just as occurred in Ecuador. ${ }^{17}$

\subsection{Equatorial Constitution from 2008}

At this moment, the specific analysis of the Ecuadorian Constitution ${ }^{18}$ is important because, together with Bolivian, it represents the greatest advance in relation to indigenous rights in Latin America.

Already in 1998 the Ecuador Constitution that recognized the State as plurinational had been promulgated. However, considering that the country is composed mostly of natives, there was a great deal of pressure to make the transformations even deeper. Thus, after years of debate, a new Constitution was approved, in 2008, whose norms were more protective and radical, not only in relation to Indigenous Peoples, but also in relation to the environment, originating what is called a "biocentric turn".19

\footnotetext{
15 ARAUJO JR., Julio José. Direitos territoriais indígenas: uma interpretação intercultural. Rio de Janeiro: Processo, 2018, p. 5.

16 ARAUJO JR., Julio José. Direitos territoriais indígenas: uma interpretação intercultural. Rio de Janeiro: Processo, 2018, p. 5.

17 HOGEMANN, Edna Rachel Rodrigues Santos. Constituição, Direitos Humanos e Pluralismo Jurídico: a possibilidade de controle à jurisdição indígena no Brasil a partir da comparação com a Constituição equatoriana. Revista Brasileira de Teoria Constitucional. Salvador, v. 4, n. 1, jan/jun. 2018. Available at: <http://www.indexlaw.org/index.php/teoriaconstitucional/article/view/4408>. Last access: 5 Jan. 2019, p. 115.

18 EQUADOR. Constituición del Ecuador. Available at: <www.acnur.org>.

19 ARAUJO JR., Julio José. Direitos territoriais indígenas: uma interpretação intercultural. Rio de Janeiro: Processo, 2018, p. 92.
} 
The Nature or Mother Earth, free translation of the term umacma, in the old umac language, was recognized like subject of rights. In the same sense, the idea of buen vivir or umac kawsay, which means, basically, that people have the right to exercise their rights in harmonious coexistence with Nature. ${ }^{20}$

The Ecuadorian Constitutional Charter followed the line of the Brazilian, and dealt with indigenous affairs in several articles, besides having a specific chapter to do so. As in Brazil, there was intense participation of indigenous communities in their elaboration.

It recognized indigenous languages as an official language (Article 2), ${ }^{21}$ and determined the recognition by the State of the social, political and economic organization of these ethnic groups (Article 57). However, its main innovation was to recognize the existence of an indigenous jurisdiction, based on ancestral traditions and on its own law, whose decisions must be respected by the institutions and public authorities (article 171).

The existence of an indigenous jurisdiction ensures that these ethnic groups are represented and have their rights guaranteed in a more effectively manner. In other words, it gives them a voice, allows them to decide on their own course, according to their convictions and traditions.

According to Hogemann, there are limits, in the Ecuadorian Constitution, regarding indigenous justice, the new text provides "material limits (at the constituted precepts and recognized human rights in international instruments) and territorial (limiting the manifestations of the extension of the indigenous communities) and those manifestations, allowing, if necessary, the possibility to verify the decisions coming from the this jurisdiction in the process of constitutionality control".22

The occurrence of limits to be followed by the indigenous communities is one of the reasons why Hogemann supports the approximation between the Ecuadorian Constitution and the Brazilian, and it should be allowed, in Brazil, the existence of a justice that is not state-owned. The control of constitutionality, for the theoreticians opposed to the recognition of a jurisdiction distinct from the state-owned, may be an alternative.

20 Both terms - buen vivir and pachamama are difficult to conceptualize, precisely because they originate in indigenous worldviews, which the non-natives have difficulty understanding. However, they can be understood, in general terms, as living well, in harmony with nature, which is not an object but a subject, and must be respected.

21 Spanish is the official language of Ecuador; Castilian, Kichwa and Shuar are official languages of intercultural relationship. The other ancestral languages are of official use for the Indigenous Peoples in the areas where they live and, in the terms, established by law. The State will respect and encourage its conservation and use.

22 HOGEMANN, Edna Rachel Rodrigues Santos. Constituição, Direitos Humanos e Pluralismo Jurídico: a possibilidade de controle à jurisdição indígena no Brasil a partir da comparação com a Constituição equatoriana. Revista Brasileira de Teoria Constitucional. Salvador, v. 4, n. 1, jan/jun. 2018. Available at: <http://www.indexlaw.org/index.php/teoriaconstitucional/article/view/4408>. Last access: 5 Jan. 2019, p. 120. 


\subsection{Bolivian Constitution from 2009}

The Constitution of Bolivia was the one that advanced the most, since it established a true Plurinational State. This can be seen from the preamble to the Constitution, which states that "el pueblo boliviano, de composición plural, desde la profundidad de la historia, inspirado em las luchas del pasado, en la sublevación indígena anticolonial (...) construímos un nuevo Estado". ${ }^{23}$

Its promulgation counted of ample indigenous participation and had close relation with the election of a President also indigenous. Like the Ecuadorian Constitution, it declared the indigenous languages as official and increased the list of constitutionally guaranteed rights. ${ }^{24}$

However, as far as legal pluralism is concerned, it went further. Indigenous jurisdiction was created, with the same legal authority and hierarchical structure as the Brazilian nation-state (article 179), with indigenous authorities and their own procedures based on cultural precepts (article 190). A Plurinational Constitutional Court was also created, composed of elected magistrates, with representation of the ordinary and indigenous system (article 197). This is another step towards the representativeness and effective participation of the indigenous population.

The new text, when recognizes "the authenticity of indigenous justice by admitting legal pluralism, in an equal coexistence between state and indigenous justice", it makes a step forwards to break with capitalism and colonialism in Latin America. According with Wolkmer and Ronchi, "It can not be said that there has been a definitive break with colonialism and capitalism, but it is on the way. It is important that there are no setbacks, only advances".25

The equality between state justice and indigenous justice, within the constitutional framework, provided a great advance in the context of legal pluralism. The explanation of this movement is based on the emancipation to which the new Latin American constitutionalism aims. As Wolkmer and Ronchi warned, the recognition in the Constitution of pluralism does not completely end the cycle of domination. There is a process of disruption in the gears that are affected by colonialism, gradually seeking measures to meet the essence of Latin America, in the figure of the roots, for example, of indigenous culture.

\footnotetext{
23 "The Bolivian people, of plural composition, from the depth of history, inspired by the struggles of the past, in the anticolonial indigenous uprising (...) we built a new State". BOLÍVIA. Constitución Política del Estado (CPE) - Bolívia. Available at: <www.oas.org >

24 ARAUJO JR., Julio José. Direitos territoriais indígenas: uma interpretação intercultural. Rio de Janeiro: Processo, 2018, p. 95.

25 WOLKMER, Antonio Carlos; RONCHI, Maria Laura. Processos constituintes latino-americanos e a presença dos movimentos sociais no Brasil e na Bolívia. Revista Culturas Jurídicas, v. 3, n. 6, 2016, p. 167.
} 


\subsection{The Problem of (In)Effectiveness of the Constitutional Command- ment}

The main problem that we can point out in relation to this scenario is that despite the fact that several indigenous rights have been affirmed, these Constitutions maintained the same legal-political system based on hyper-presidentialism and the hypertrophy of the Executive Power, which prevented their implementation.

It's what Gargarella calls the "machinery house of the Constitution",26 that is, an organic part of the Constitutions that remains intact despite the great transformations that occur in the dogmatic part. This mismatch between the organic and the dogmatic generates conflicts between them and the those who suffers the consequences of this are those that see their rights only in the paper. On the subject, Araújo Jr. elucidates that: "The implementation of the Andean constitutional projects is a complex process, since certain guidelines conflict with private economic interests and divergent understandings about the role of the State in the promotion of citizenship and in the fight against inequalities..27

The impediments imposed are of various natures. As an example, the Jurisdictional Discipline Law, approved in 2010 in Bolivia, imposes restrictions without numbers on the exercise of indigenous jurisdiction in the country. ${ }^{28}$

Thus, in order to ensure that constitutional predictions are put into effect, bringing about a transformation in social reality, it takes much more than simply giving rights or creating institutions. A radical change is required in the state model and in the legal-political form adopted, which has not occurred in any of the Latin American countries. Perhaps that is why today there is a conservative wave so strong that it spreads across the continent and threatens the indigenous conquests that theoretically are already consolidated.

Despite this, it is necessary to give due importance to the transformations brought by the new Latin American constitutionalism. From the recognition of indigenous rights in the Constitutions, these peoples came to be understood as subjects of rights, as part of the community, even if only on paper. This provide them access to the heart of the political community to be progressively opened for the indigenous.

\footnotetext{
26 GARGARELLA, Roberto. La sala de máquinas de la Consituición: dos siglos de constitucionalismo en América Latina (1810-2010). Buenos Aires: Katz Editores, 2014. p 247.

27 ARAUJO JR., Julio José. Direitos territoriais indígenas: uma interpretação intercultural. Rio de Janeiro: Processo, 2018, p. 99.

28 ARAUJO JR., Julio José. Direitos territoriais indígenas: uma interpretação intercultural. Rio de Janeiro: Processo, 2018, p. 98.
} 


\section{LEGAL PLURALISM}

In Latin America, the new constitutionalism is associated with the yearnings of groups, until then, completely outside the egalitarian principle. The legitimacy of the representatives of the sovereign states in this path was questioned and, with this, the society began a process of analysis on the structure conveyed by the government. The indigenous, in the context under examination, have consolidated the need to recognize their rights at the state level..$^{29}$

It's noted thus "The continuous struggle of indigenous groups, characterized by a set of demands and political practices that call for a deepening of democracy and participation, with the disruption of clientelism."30 The State justice, therefore, in the reality of some sovereign States of Latin America, is no longer unified, giving a portion of its space to indigenous justice, theoretically fomenting legal pluralism embodied in the Constitution. However, the true scope of indigenous justice and its observance is problematic, since the confirmation of the existence of this justice by the State can generate the dissatisfaction of several power holders in the society.

Legal pluralism comprises several legal systems in a specific territory. The plurality of cultures, it is worth mentioning, is reverberated in the manifold manifestations tangent to the legal systems. As explained in the other section, referring to the new Latin American constitutionalism, sovereign states such as Venezuela, ${ }^{31}$ Ecuador and Bolivia, at least theoretically, allowed a manifestation of the indigenous legal system in constitutional seat. There was the consubstantiation of an elementary measure for the even broader recognition of indigenous rights. Legal pluralism in this sense can be defined as follows: "By Legal Pluralism one must understand the possibility that, in the same territory (space-time context), different normative statements and with them, a plurality of legal systems coexist; in other words, appropriate legal statements or corresponding to a real-factual world".32

\footnotetext{
29 ALMEIDA, Mariana Corrêa de. A cultura legal emergente latinoamericana: o pluralismo jurídico rompendo os laços imperialistas no direito. Revista Brasileira de Estudos Latino-americanos, v.1, n.1, p. 38-50, jun. 2011. Available at: <https://rebela.emnuvens.com.br/pc/article/view/21>. Last access: 10 Dec. 2018.

30 ALMEIDA, Mariana Corrêa de. A cultura legal emergente latinoamericana: o pluralismo jurídico rompendo os laços imperialistas no direito. Revista Brasileira de Estudos Latino-americanos, v.1, n.1, p. 38-50, jun. 2011. Available at: <https://rebela.emnuvens.com.br/pc/article/view/21>. Last access: 10 Dec. 2018.

31 The Constitution of Venezuela was enacted in 1999 and, as early as it's preamble, recognized the importance of the struggles perpetrated by Venezuelan ancestors. The rights of Indigenous Peoples are reflected in the Charter of the Venezuelan Republic. There is a chapter destined, therefore, to the prediction of the mentioned rights, being assured the participation of the natives in the formation of the collective will of the Venezuelan State. VENEZUELA. Constituición de la República Bolivariana de Venezuela. 1999 Available at: <https://www.oas.org/juridico/mla/sp/ven/sp_ven-int-const.html>. Last access: 8 Jan. 2019.

32 CASTAÑEDA, Carlos Adolfo Rengifo; JARAMILLO, Eduard Mauricio Wong; POSADA, Jorge Gregorio. Pluralismo Jurídico: implicaciones epistemológicas. Inciso. Vol. 15, 2013, p. 33. Available at: <http://revistas.ugca.edu. co/index.php/inciso/article/view/71>. Last access: 2 Jan. 2019.
} 
From the concept brought up, there remains the understanding according to which pluralism is based on differences. Thus, the plural perspective is one that recognizes, among the particulars of each grouping, sufficient reasons for a distinct regency in the legal fields. Pluralism thus opposes legal monism. While the former contemplates the essence of each group, especially in the theoretical aspect, the latter derives from a look limited to generalization, mirrored in the colonizing interference before the colonized.

Legal pluralism, in addition to its comparison with monism, requires a rupture concerning the prospect of domination exercised by laws rooted in colonizing precepts. The occurrence of pluralism is based on the constitutional commitment to an equitable valuation of ordinary and indigenous justice. Indigenous justice, in the meantime, must have the same importance attributed to the ordinary one. In addition, the hierarchy between the aforementioned subdivisions of justice must be the same. ${ }^{33}$

When investigating legal pluralism, exemplified by indigenous practices, plural understandings need to be embraced by recognition. It's denied, in this sense, a higher hierarchy of one view over another. The new Latin American constitutionalism has, as one of its pretensions, the development of a more pluralistic view in the context of Latin America. The central figure of the State, in Law, tends to rule out any other consolidation of legal pluralism. Indigenous justice, as a source, can help in the deconfiguration of a system that is generically put and accepted by society. ${ }^{34}$

Still related to the debate regarding the hierarchy between state and indigenous jurisdiction, Curi explains that the Indigenous Peoples have their own legal system and norms "are not restricted to a simplicity determined by tradition and servile obedience, by means of a mental inertia (...) but with particular characteristics, which should not be placed in a value judgment if they are better or worse". Their system has "their own way of expressing their right, which is through behaviours, orally, passing from generation to generation, in a movement alive and continuous".35

Curi's thesis, thus, removes a vision directed to the merit of the cultural expression of the natives. Their Law is based on the protection on habits, which derive from accumulated knowledge over the years. Its form of organization and the decisions handed down by its authorities are based on the culture of these peoples. The vision of reality changes according to the culture and the main aspect of interculturalism is the protection of the forms of expression in society.

33 WOLKMER, Antonio Carlos. Pluralismo Jurídico: fundamentos de uma nova cultura no Direito. 5. ed. São Paulo: Saraiva, 2015, p. 166.

34 ARAUJO JR., Julio José. Direitos territoriais indígenas: uma interpretação intercultural. Rio de Janeiro: Processo, 2018, p. 88.

35 CURI, Melissa Volpato. O Direito Consuetudinário dos Povos Indígenas e o Pluralismo Jurídico. Espaço Ameríndio, Porto Alegre, v. 6, n. 2, jul./dez. 2012, p. 232. Available at: <https://seer.ufrgs.br/EspacoAmerindio/ article/view/32216>. Last access: 22 Dec. 2018. 
In addition, it is concerned with possible divergences in the coexistence of different legal regimes. This is because it is possible to see the occurrence of conflicts between members of groups in which there is a different application of legal regimes. The search for congruence and, therefore, for the solution on these occasions, needs to be analyzed. ${ }^{36}$

The subject of indigenous law provides doctrinal reflections regarding its characterization as customary law or, if its classification is not admitted in this category, it would need to be observed in a different way, as if it were an autonomous category. ${ }^{37}$

In Wolkmer' words, "It is imperative to open up to an anthropological, sociological and historical perspective if one accepts the legal nature of the normative systems of the indigenous populations. Contemporarily in-laws of Indigenous Peoples (peasant communities)". For the author there are two phases in the treatment of Indigenous Law: "a) firstly, the adequacy or otherwise of qualifying Indigenous Law with the adjectival of being customary or not. To what extent is the term Indigenous Law confused or not with Common Law?". The second phases is link to the followings questions: "b) In the Latin American tradition, how have the relations between Indigenous Law and State Law been presented? A relationship of subordination, autonomy or interaction? For many theorists, Indigenous Law is a customary law, for others, it deals with distinct manifestations with their own specialties" ${ }^{\prime \prime 3}$.

Melissa Curi, ${ }^{39}$ guides indigenous law from her customary practices. Thus, it establishes the behaviours as nodal for the identification of customary law in the indigenous field. From the point of view of positive law, behaviours are not forgotten as sources of lesser relevance. The indigenous Law, thus, backed by behaviours, is linked to the structure of the indigenous group and its manifestations.

As it has been underlined by Fajardo the indigenous justice has the substantive competence "to know all the matters it deems appropriate, within its own territorial scope (...) and, even extraterritorially, with respect to its members, provided that certain conditions are respected. Neither the constitutional texts of the Andean countries nor

\footnotetext{
36 ARAUJO JR., Julio José. Direitos territoriais indígenas: uma interpretação intercultural. Rio de Janeiro: Processo, 2018, p. 74.

37 WOLKMER, Antonio Carlos. Pluralismo Jurídico: fundamentos de uma nova cultura no Direito. 5. ed. São Paulo: Saraiva, 2015, p. 235-236.

38 WOLKMER, Antonio Carlos. Pluralismo Jurídico: fundamentos de uma nova cultura no Direito. 5. ed. São Paulo: Saraiva, 2015, p. 235-236.

39 CURI, Melissa Volpato. O Direito Consuetudinário dos Povos Indígenas e o Pluralismo Jurídico. Espaço Ameríndio, Porto Alegre, v. 6, n. 2, jul./dez. 2012, p. 231. Available at: <https://seer.ufrgs.br/EspacoAmerindio/ article/view/32216>. Last access: 22 Dec. 2018.
} 
ILO Convention $169^{40}$ establish a limit on the matters or the seriousness of the facts that the Indigenous Law may know".41

In short, despite the essence of the constitutional predictions in the Andean countries, it is close to recognizing a special indigenous justice, coordinated by the authorities of the indigenous groups, there are peculiarities regarding specific considerations in the regulation of that justice, as can be seen from Constitutions of each State. ${ }^{42}$

The Brazilian reality demonstrates the lack of concern of the authorities with the possibility of an indigenous jurisdiction, in the core of which there is protection of cultural diversity. ILO Convention 169 allows for a more careful reflection on the subject. The State, thus disregarding the peculiarities of indigenous culture, subjects the indigenous groups to their decisions, the content of which can often dissipate completely from the behaviors and manifestations of those groupings, breaking their essence. ${ }^{43}$

Legal pluralism, as far as indigenous groups are concerned, was closely reflected in the Andean countries as a result of the movement of the new Latin American constitutionalism and consideration of Convention 169 of the ILO. With the recognition, by the State, of the indigenous justice, the violence diminishes and the democracy is strengthened. Indigenous jurisdiction is exercised by authorities belonging to indigenous groups. This performance of jurisdiction is regulated by the behaviors and practices of the groups in question and there is a territorial restriction, since the indigenous authorities have the jurisdictional power in the indigenous lands. ${ }^{44}$

ILO Convention 169 advocates the recognition of indigenous jurisdiction, but the need for protection of human rights is ascertained. In summary, the decisions handed down within the scope of indigenous justice conform to certain limits, which relate mainly to the rights of the human person and to the essential purposes of the constitution of a certain sovereign State. The Latin American states, in which there was

40 The Convention $\mathrm{n}^{\circ} .169$ of the International Labor Organization (ILO) began its international operation on September 5, 1991. Under Brazilian law, it entered into force on July 25, 2003. The international treaty in question deals with the Indigenous Peoples and tribal peoples, especially in the respect for the fundamental rights of these peoples (Brasil, 2004).

41 FAJARDO, Raquel Z. Yrigoyen. . Pluralismo jurídico, derecho indígena y jurisdicion especial en los países andinos. El otro Derecho, ISLA, Bogotá, n. 30, p. 182, jun. 2004. Available at: <https://www.cejamericas.org/ Documentos/DocumentosIDRC/128elotrdr030-06.pdf>. Last access: 15 Dec. 2018.

42 FAJARDO, Raquel Z. Yrigoyen. . Pluralismo jurídico, derecho indígena y jurisdicion especial en los países andinos. El otro Derecho, ISLA, Bogotá, n. 30, p. 182-184, jun. 2004. Available at: <https://www.cejamericas. org/Documentos/DocumentosIDRC/128elotrdr030-06.pdf>. Last access: 15 Dec. 2018.

43 HOGEMANN, Edna Rachel Rodrigues Santos. Constituição, Direitos Humanos e Pluralismo Jurídico: a possibilidade de controle à jurisdição indígena no Brasil a partir da comparação com a Constituição equatoriana. Revista Brasileira de Teoria Constitucional. Salvador, v. 4, n. 1, jan./jun. 2018, p. 125. Available at: <http:// www.indexlaw.org/index.php/teoriaconstitucional/article/view/4408>. Last access: 5 Jan. 2019.

44 FAJARDO, Raquel Z. Yrigoyen. . Pluralismo jurídico, derecho indígena y jurisdicion especial en los países andinos. El otro Derecho, ISLA, Bogotá, n. 30, p. 182-184, jun. 2004. Available at: <https://www.cejamericas. org/Documentos/DocumentosIDRC/128elotrdr030-06.pdf>. Last access: 15 Dec. 2018. 
recognition of indigenous jurisdiction, as a rule, determine that specific laws resolve conflicts between jurisdictions. Thus, in such cases, the States allow the formulation of decisions regarding the jurisdiction devoid of their interference, in spite of the fact that limits are exalted. ${ }^{45}$

\subsection{The Indigenous Jury in Brazil}

This Chapter would like to open a debate about the possibility to effectively implement legal pluralism in Brazil, especially with regard to indigenous legal systems. The case under analysis was judged on April 23, 2015, in the State of Roraima (Brazil), where the competent Court undertook an innovate initiative: a jury composed only by Indigenous Peoples was established for the purpose of judging an assassination attempt. The parties involved in the case were from the Macuxi ethnic group.

On January 23, 2013 a fight between three natives broke out in the Municipality of Uiramutã, in Raposa Serra do Sol. The Public Ministry denounced Elsio and Valdemir da Silva Lopes for the attempted murder of the victim Antônio Alvino Pereira. The arm and neck of the victim were injured because of the occasion. The accused were justified, claiming that they acted in self-defense, since Antonio was subjugated to the entity Canaimé, ${ }^{46}$ which, in the local indigenous culture, is related to evil. On the other hand, local indigenous leaders were not convinced of the reasoning, carried out by the accusatory defense, about the presence of the Canaimé entity. According to the leaders, the consumption of alcoholic beverages by those involved resulted in the practice of the alleged crime. ${ }^{47}$

With a view to a multidisciplinary analysis, in the plan, in the journalism, it is pertinent an allusion to the report developed by Otacílio Gabriel for a National Radio Agency, a qualification to the Brazilian Company of Communication. The report underlines that in the State of Roraima was created the first indigenous jury to judge an attempted homicide that was conducted in the community of Maturuca, situated in the Raposa Serra do Sol Indigenous Reserve in a municipality called Uiramutã, in the north of the country. Otacílio Gabriel explains that pioneer experience was only possible after multiple consultation between indigenous leaders and the representatives of local

\footnotetext{
45 FAJARDO, Raquel Z. Yrigoyen. . Pluralismo jurídico, derecho indígena y jurisdicion especial en los países andinos. El otro Derecho, ISLA, Bogotá, n. 30, p. 174-175, jun. 2004. Available at: <https://www.cejamericas. org/Documentos/DocumentosIDRC/128elotrdr030-06.pdf>. Last access: 15 Dec. 2018.

46 COSTA, Emily. Júri indígena em Roraima absolve réu de tentativa de homicídio. Roraima, 2015. Available at: $\quad$ http://g1.globo.com/rr/roraima/noticia/2015/04/juri-indigena-absolve-reu-de-tentativa-de-homicidio-e-condena-outro-em-rr.html> Last access: 19 Aug. 2019.

47 UNIVERSIDADE ESTADUAL DE RORAIMA. Roraima tem primeiro júri popular indígena. Available at: <https://www.uerr.edu.br/roraima-tem-primeiro-juri-popular-indigena/>. Last access: 20 Mar. 2019.
} 
judiciary. The Judge Aluizio Ferreira points out that "the initiative of the Court of Justice of Roraima aims to approximate the state of the indigenous populations".48

Based on the report, the positive aspects of the constitution of a popular jury by members of indigenous communities, who can see the process in a different way, are highlighted. The traditional way of conducting the proceedings, especially in criminal cases, leads to the imposition of a sentence as a response to the practice of a conduct conforming to a criminal type. In the case under examination, even if there is the possibility of punishment by one of the accused, as it was condemned, there is a possible way, with such a precedent, towards the recognition of a legal pluralism in Brazil, even though it is distant from other sovereign states, such as Venezuela and Bolivia. It is reasonable to adopt the expression "mitigated pluralism", a nomenclature already used by Catusso. ${ }^{49}$

On the case judged by the Court of the Jury, the Judgment Council, presided over by a Judge of Law, was composed only of indigenous members because the indigenous are "living in a context different from that faced by the rest of society, have their own rules, fight for them and apply them when necessary (...). Otherwise, the accused would be punished twice for practicing the same fact, for the rules of tribe and for the Judiciary". In this way, the president of the Council is the only member not indigenous who will apply the decision of the jury by using Brazilian law "in accordance with what the tribe judges to be more fair to the case in question, not hurting the cultural environment of the indigenous ethnic groups".50

The above analysis approaches the so-called "mitigated pluralism", since, despite the fact that there is no confirmation by the State of the existence of an indigenous jurisdiction, there is an attempt to reconcile the customary law of the Indigenous Peoples with state-owned justice. In the case of the trial mentioned in Roraima, the Judgment Council of the Court of the Jury was composed only of Indigenous Peoples. It is known that, in the jury, jurors vote, by means of ballots, in accordance with their intimate conviction.

The assessment of the evidence and arguments of the parties to the proceedings at the heart of the Jury's Court is therefore subject to the filter of intimate conviction. Such a conclusion comes, in particular, from the experiences and, hence, from

48 GABRIEL, Otacílio. Roraima realiza julgamento com primeiro júri popular indígena do País. Available at: <http://radioagencianacional.ebc.com.br/geral/audio/2015-04/roraima-realiza-julgamento-com-primeiro-juri-popular-indigena-do-pais\#player-radioagencia-nacional>. Last access: 19 Aug. 2019.

49 CATUSSO, Joseane. Pluralismo jurídico: um novo paradigma para se pensar o fenômeno jurídico. Revista Eletrônica do CEJUR, Curitiba, v. 1, n. 2, ago./dez. 2007, p. 130

50 FERREIRA, Isabela Natani; POLACHINI, Beatriz; ABÍLIO, Adriana Galvão Moura. A competência do Tribunal do Júri para julgar os crimes cometidos por indígenas. Revista Fafibe, 2016, p. 101. Available at: <http://unifafibe.com.br/revistasonline/arquivos/revistafafibeonline/sumario/49/16032017212600.pdf>. Last access: 26 Dec. 2018. 
the culture of the jury. Therefore, with the choice of indigenous jurors, it is possible that the accused will be acquitted in a claim whose contents would be totally disregarded if judged by members outside the indigenous community and unaware of their particularities.

Within the scope of the Research Center on Practices and Legal Institutions of the Federal Fluminense University (NUPIJ-UFF), there was a debate on the First Jury Tribunal, composed only of Indigenous Peoples, held in Brazil..11

Speaker Edson Damas ${ }^{52}$ presented his vision as a member of the Public Prosecutor's Office. In his understanding, the ideal is for indigenous culture to be respected, so that internal conflicts within the community can be resolved through the Indigenous Peoples themselves, that is, the interference of the Judiciary should not occur with regard to the groups on display.

Judge Aluízio Ferreira, ${ }^{53}$ who was in charge of the presidency of the Court of the Indigenous Jury, explained that there were already talks and previous experiences regarding the possibility of this Court of the Jury, looking for a suitable place for the trial. Previously to the Jury, numerous discussions took place and the judge understands it as constructed. According to him, the Jury took place in April 2015. Individuals participating in the community were selected for the draw. Thus, the Jury was established with respect to the guidelines contained in ILO Convention 169. The judge said that the prosecutor was present at the time of the draw and at all times.

Regarding the role of the operators of the Law, the magistrate reported it as "normal". The anthropologist Prof. Ronaldo Lobão intervened and problematized the expression "normal", opting for "usual". At this point, the pertinence of the Professor's comment is emphasized, since the "normal" nomenclature is imprecise and designates, from an unequivocal and unilateral parameter, specific practices. ${ }^{54}$

\footnotetext{
51 LOBÃO, Ronaldo. I Júri Popular Indígena realizado no Brasil. In: Seminário do Laboratório de Estudos da Cidadania, Administração de Conflito e Justiça do Departamento de Antropologia da Universidade de Brasília (CAJU-UnB). Brasília: Universidade de Brasília, 2015. Available at: <https://www.youtube.com/watch?v=oYRkFI5OhSw>. Last access: 10 Jan. 2019.

52 SILVEIRA, Edson Damas da. O olhar de um membro do Ministério Público. In: Conversa sobre Primeiro Tribunal do Júri na Terra Indígena Raposa Serra do Sol. Niterói: Universidade Federal Fluminense, Faculdade de Direito, Núcleo de Pesquisa sobre Práticas e Instituições Jurídicas (NUPIJ-UFF). Niterói: Universidade Federal Fluminense, 2016. Available at: <https://www.youtube.com/watch?v=8UP2XOsfj20>. Last access: 8 Jan. 2019.

53 FERREIRA, Aluízio. O olhar do magistrado que presidiu o Tribunal do Júri Indígena. In: Conversa sobre Primeiro Tribunal do Júri na Terra Indígena Raposa Serra do Sol. Niterói: Universidade Federal Fluminense, Faculdade de Direito, Núcleo de Pesquisa sobre Práticas e Instituições Jurídicas (NUPIJ-UFF). Niterói: Universidade Federal Fluminense, 2016. Available at: <https://www.youtube.com/watch?v=8UP2XOsfj20>. Last access: 5 Jan. 2019.

54 LOBÃO, Ronaldo. I Júri Popular Indígena realizado no Brasil. In: Seminário do Laboratório de Estudos da Cidadania, Administração de Conflito e Justiça do Departamento de Antropologia da Universidade de Brasília (CAJU-UnB). Brasília: Universidade de Brasília, 2015. Available at: <https://www.youtube.com/watch?v=oYRkFI5OhSw>. Last access: 10 Jan. 2019.
} 
The judge reported on this path an incompatibility between the culture of the Indigenous Peoples present in the Jury and recurrent judicial practices, such as defense and prosecution under a kind of theatrical form. The magistrate also pointed out that the Court of Appeal, through tools of state law, confirmed the decision from the Jury on the formal aspect.

The defense lawyer at the Jury Court held in Roraima, Thais Lutterback, ${ }^{55}$ in the lecture, exposes the differences as important in the analysis of the Jury Tribunal composed only by Indigenous Peoples. The lawyer argued that, even from a law-only perspective, she invoked in the defense legal figures such as self-defense and the unenforceability of different conduct.

It appears from the lawyer's discourse that there was a didactic importance with the community about the role of the Jury. The interculturalism and the distance between theory and practice regarding indigenous rights were supported by the patroness of the defense. The defense, according to Lutherback, aimed at the reflection among communities related to the commission of the alleged crime of attempted murder. According to Julio Macuxi, authority in the indigenous community determines the measures appropriate to the conduct practiced by members of said community. As explained in the resolutions of conflicts before the community, there are no figures of the defense and the Public Prosecutor.

According to Macuxi, there are three degrees of justice in the indigenous legal system of that region. The indigenous authorities are responsible for judging the conduct contrary to, for example, respect. An interesting point was that the prosecutor was sentenced, later to the Jury, by the community leaders because of the incisive way in which the accusation was brought before the jury court within the indigenous community. This elucidates, once again, the difference between cultures, visualized by the binomial of state justice and the customary law of indigenous communities.

Macuxi ${ }^{56}$ presented the discussions in the community about the effects of the Jury Court. The leaders drew up a new decision. He informed that some Indigenous Peoples of the group participating in the Jury called it a failed attempt. He stated that, in the indigenous community, imprisonment is not perceived as just. Macuxi explained that there was an earlier understanding, of 1977, which curtails the consumption

55 AZEVEDO, Thaís Maria Lutterback Saporetti. O olhar de um dos advogados de defesa. In: Conversa sobre Primeiro Tribunal do Júri na Terra Indígena Raposa Serra do Sol. Niterói: Universidade Federal Fluminense, Faculdade de Direito, Núcleo de Pesquisa sobre Práticas e Instituições Jurídicas (NUPIJ-UFF). Niterói: Universidade Federal Fluminense, 2016. Available at: <https://www.youtube.com/watch?v=8UP2XOsfj20>. Last access: 6 Jan. 2019.

56 MACUXI, Júlio. O olhar de uma das lideranças indígenas. In: Conversa sobre Primeiro Tribunal do Júri na Terra Indígena Raposa Serra do Sol. Niterói: Universidade Federal Fluminense, Faculdade de Direito, Núcleo de Pesquisa sobre Práticas e Instituições Jurídicas (NUPIJ-UFF). Niterói: Universidade Federal Fluminense, 2016. Available at: <https://www.youtube.com/watch?v=8UP2XOsfj20>. Last access: 11 Jan. 2019. 
of alcoholic beverage and the victim did it, reason for which already it would be punished. The objective of the Indigenous Peoples, for Macuxi, is the independence of the community for the solution of their own conflicts. He also argued that cases brought to justice were not usually met with satisfaction by the victim's next-of-kin.

Given the explanation provided above, there is a clear divergence between the idea of justice in state jurisdiction and in indigenous practices. The usual element, in Macuxi's speech, can be recognized in the understanding of community leaderships since 1977.

The professor and anthropologist Ronaldo Lobão, who was present at the trial by the indigenous jury court of indigenous defendants in Roraima, gave a speech at the Seminar held at the Institute of Social Sciences of UnB on May 11, 2015. One of the malocões, ${ }^{57}$ according to the professor, has a special meaning for the natives and was chosen for consubstantiation of the Court of the Jury.

Lobão ${ }^{58}$ dissected the composition of the Jury's Court, mentioning his co-director of the PhD in Sociology and Law, Thais Lutterback, as one of the defense attorneys. The professor emphasized that in Roraima, the Judiciary has been involved in innovations related to crimes committed by Indigenous Peoples in the face of Indigenous Peoples in the territorial field of the groups inhabited by them.

The Judge Aluizio Ferreira invoked the principle of a double ius puniendi: the double right to punish means that "when indigenous groups deem indigenous crimes on indigenous lands, such a judgment would precede the State's right to make judgment, that is to say, the State should not judge, then it is not even a sealing discussion of the bis in idem." 59

The so-called principle of double ius puniendi, in this plane, would not be equivalent to the ne bis in idem fence. The idea of ne bis in idem presupposes the recognition of the indigenous jurisdiction as an alternative to the state. That is why, technically, since indigenous jurisdiction in Brazil is not yet recognized, the principle of double ius

\footnotetext{
57 According to Marques, "malocão is a community space used by Indigenous Peoples in the Amazon region and specifically in Roraima. Each village has its own structure of maloca, with unique characteristics that help distinguish one people from another. The term maloca is known by the Macuxi peoples as a large house (a place where they meet for various activities such as community luncheon, parties, meetings and other events of community interest). MARQUES, Élder Silva. Conhecendo o Malocão. Available at: <http://valoreseidentidademacuxi.blogspot.com/2014/01/conhecendo-o-malocao.html>. Last access: 31 Mar. 2019.

58 LOBÃO, Ronaldo. I Júri Popular Indígena realizado no Brasil. In: Seminário do Laboratório de Estudos da Cidadania, Administração de Conflito e Justiça do Departamento de Antropologia da Universidade de Brasília (CAJU-UnB). Brasília: Universidade de Brasília, 2015. Available at: <https://www.youtube.com/watch?v=oYRkFI5OhSw>. Last access: 10 Jan. 2019.

59 LOBÃO, Ronaldo. I Júri Popular Indígena realizado no Brasil. In: Seminário do Laboratório de Estudos da Cidadania, Administração de Conflito e Justiça do Departamento de Antropologia da Universidade de Brasília (CAJU-UnB). Brasília: Universidade de Brasília, 2015. Available at: <https://www.youtube.com/watch?v=oYRkFl5OhSw>. Last access: 10 Jan. 2019.
} 
puniendi may be a response. The possibility of two trials, then, would suggest, to state justice, a departure from hypotheses already judged by the natives.

The lawsuit, referring to the first Judgment Council formed by Indigenous Peoples in Brazil, came from an attempted murder allegedly perpetrated by two Indigenous Peoples of a given community in relation to an indigenous person from another community. The alleged crime did not occur specifically on indigenous land. The matter was referred to the police station. The defense argument of the defendants related to the fact that they saw in the victim a representation of an evil illustration, which would have to be eliminated. If the hypothesis were analyzed with a non-indigenous perspective, there would be no understanding related to the defense of the defendants. ${ }^{60}$

Regarding the reason why the natives agreed with the Jury Court in the community, Lobão ${ }^{61}$ stated that it would be an expectation of learning, as if it were an ethnography. The natives would thus try to understand the circumstances of the trial in state justice. The anthropologist worried about the outcome of the Jury Court in the community. The objective would be not to blame the victim and to make conversation between communities and peace possible.

On November 13, 2018, a seminar entitled "Indigenous Rights and Causes: The Federal Supreme Court in the field of observation" was held at the Faculty of Law of the Federal Fluminense University, in which issues such as indigenous rights were debated. The defense lawyer, at the jury court studied in this research, Thais Lutterback, gave a speech on the occasion.

In the seminar, Lutterback extolled the case as an attempted murder, in which the native defendants attempted measures to marshal another native life because they believed the victim was possessed by a bad spirit. The belief of the accused in the presence of the spirit at that moment, according to the defense, was due to the constant, unexplained deaths in the indigenous community. The criminal situation, according to the lawyer, occurred in the village and not in the indigenous territory. There was, thus, arrest in flagrant.

The day after the trial by state court, Lutterback said that the community resorted to the case, but from their behaviours. The lawyer detailed that in the state justice, even with the composition of the Council of Sentence by the natives, one defendant was punished and the other, acquitted. The natives, in this way, were not compatible

60 LOBÃO, Ronaldo. I Júri Popular Indígena realizado no Brasil. In: Seminário do Laboratório de Estudos da Cidadania, Administração de Conflito e Justiça do Departamento de Antropologia da Universidade de Brasília (CAJU-UnB). Brasília: Universidade de Brasília, 2015. Available at: <https://www.youtube.com/watch?v=oYRkFI5OhSw>. Last access: 10 Jan. 2019.

61 LOBÃO, Ronaldo. I Júri Popular Indígena realizado no Brasil. In: Seminário do Laboratório de Estudos da Cidadania, Administração de Conflito e Justiça do Departamento de Antropologia da Universidade de Brasília (CAJU-UnB). Brasília: Universidade de Brasília, 2015. Available at: <https://www.youtube.com/watch?v=oYRkFI5OhSw>. Last access: 10 Jan. 2019. 
with the state attempt to approach, because the founding characteristics of the cultures are intrinsically different. The state response, therefore, did not live up to the expectations of the Indians, who, according to Lutterback, considered the trial as disrespectful and brutal.

\section{CONCLUSION}

The new Latin American constitutionalism represented, for indigenous groups, a response to long-awaited expectations. From this constitutional movement, the natives obtained the recognition of rights by the State. Thus, from a theoretical point of view, their rights were constitutionally foreseen.

With the prediction of their rights in the Constitution, a real expectation regarding respect to the particularities of the indigenous groups is allowed. In some Latin American states, such as Ecuador and Bolivia, also supported by ILO Convention No. 169 , the existence of an autonomous indigenous justice system was established in what concerns state justice. This means, in practice, that the solutions to conflicts by the authorities of indigenous communities are constitutionally protected.

The theoretical framework, however, indicated the determination, in some legal systems, of limits on possible decisions originating from indigenous justice, which would be covered by Convention 169 of the ILO. An example is the prohibition of human rights abuses, which are essentially covered by international treaties relating to the human person.

In addition, it was approached the distinction between monism and legal pluralism, as well as the relation between them and the historical roots of Latin America. Monism is linked to a European and liberal perspective of domination, of colonization. The figure of the "other", under the bias in question, is subject to the orders of the holders of power. The cultural peculiarities of the Indigenous Peoples, due to colonization, were, in many cases, compromised.

The monism throws, above all, the vision according to which only the state jurisdiction must be observed. Any attempt away from the state purpose must, under this argument, be curtailed. Monism is directed to one-sidedness and therefore despises the plural.

Legal pluralism, on the other hand, means the simultaneous existence of disparate legal systems. For example, in the pluri-national State of Bolivia, there is both state jurisdiction and indigenous jurisdiction, simultaneously. The power to "say the right" does not belong, therefore, only to a certain group. Indigenous jurisdiction affords decimated groups the chance of resolving conflicts among their members in the territory of which they are a part. The constitutional recognition of the indigenous special justice 
is a great step for the protection of the particularities and, consequently, of the indigenous culture.

In the course of the study, a certain divergence between the nomenclature related to "Indigenous Law" was verified. Some authors opt for the understanding of this Law as customary, while others defend the existence of an indigenous legal system, depositing, in the nomenclature "Law", a connotation of legal monism.

Another noteworthy aspect is that only the constitutional provision of legal pluralism does not automatically lead to the guarantee of the rights contained in the Constitution. The sectors that hold power in the social sector, often dissatisfied with the recognition of the rights in question, are trying to stop it.

Faced with this dilemma associated with monism and legal pluralism, two visions were highlighted: that of mitigated pluralism, illustrated by the concrete case studied, related to the Court of the Indigenous Jury and that of full juridical pluralism. The final opinion on the subject will be exposed later to brief considerations regarding the hypothetical case investigated in this research.

The concrete case in which the current search was conducted covers the first Jury Court formed exclusively in the Corps of Jurors by indigenous members. The trial materialized on April 23, 2015. The narrative of the facts shows the commission of an alleged crime of attempted homicide by two Indigenous Peoples of a specific community through an indigenous person from another community.

According to the lectures researched on the event itself, the participants reported on the will to learn from the Indigenous Peoples and from various discussions so that the judgment by the state justice judge materialized in an environment of the indigenous community. In addition to this case, others have already been tried in Roraima and the Judiciary has shown a posture sensitive to the voice of the Indigenous Peoples.

The mitigated legal pluralism, as it developed in the Court of the Jury studied in Roraima, was the subject of much questioning by the natives. This is because a completely different congruence between reality was attempted, in a manner that the behavior of those involved, such as the Public Ministry and the defense, did not make sense to the natives.

Thus, in view of the research carried out, it is defended a perspective of complete and not mitigated legal pluralism. As a suggestion, the production of a constitutional amendment is added to guarantee the existence of an indigenous justice system, which, in line with ILO Convention 169, must respect basic principles, such as respect for human rights.

It is known that, initially, there will be several questions about the compatibility of indigenous justice with the traditional legal system. However, in spite of eventual appends to be repaired and complemented, cultural diversity must materialize not only at the theoretical level, that is, in official researches and documents, but in reality, 
whose implications define respect for the particularities of a culture, as is the case of the indigenous.

\section{REFERENCES}

ALMEIDA, M. Corrêa de. A cultura legal emergente latinoamericana: o pluralismo jurídico rompendo os laços imperialistas no direito. Revista Brasileira de Estudos Latino-americanos, v.1, n.1, p. 38-50, jun. 2011. Available at: <https://rebela.emnuvens.com.br/pc/article/view/21>. Last access: 10 Dec. 2018.

ARAUJO JR., J.J. Direitos territoriais indígenas: uma interpretação intercultural. Rio de Janeiro: Processo, 2018.

AZEVEDO, T. M. O olhar de um dos advogados de defesa. In: Conversa sobre Primeiro Tribunal do Júri na Terra Indígena Raposa Serra do Sol. Niterói: Universidade Federal Fluminense, Faculdade de Direito, Núcleo de Pesquisa sobre Práticas e Instituições Jurídicas (NUPIJ-UFF). Niterói: Universidade Federal Fluminense, 2016. Available at: <https://www.youtube.com/ watch?v=8UP2XOsfi20 >. Last access: 6 Jan. 2019.

BOLÍVIA. Constitución Política del Estado (CPE) - Bolívia. Available at: <www.oas.org>.

BRASIL. Constituição da República Federativa do Brasil de 1988. Available at: <http://www. planalto.gov.br/ccivil_03/constituicao/constituicaocompilado.htm>. Last access: 22 Aug. 2018.

BRASIL. Decreto no 5.051, de 19 de abril de 2004. Available at: <http://www.planalto.gov.br/ccivil_03/_ato2004-2006/2004/decreto/d5051.htm>. Last access: 19 Jan. 2019.

CASTAÑEDA, C. A; JARAMILLO, E. M.; POSADA, J. Pluralismo Jurídico: implicaciones epistemológicas. Inciso, v. 15, p. 27-40. 2013. Available at: <http://revistas.ugca.edu.co/index.php/inciso/article/view/71>. Last access: 2 Jan. 2019.

CATUSSO, J. Pluralismo jurídico: um novo paradigma para se pensar o fenômeno jurídico. Revista Eletrônica do CEJUR, Curitiba, v. 1, n. 2, p. 119-147, ago./dez. 2007.

CURI, M. O Direito Consuetudinário dos Povos Indígenas e o Pluralismo Jurídico. Espaço Ameríndio, Porto Alegre, v. 6, n. 2, p. 230-247, jul./dez. 2012. Available at: <https://seer.ufrgs.br/EspacoAmerindio/article/view/32216>. Last access: 22 Dec. 2018.

EQUADOR. Constituición del Ecuador. Available at: <www.acnur.org >.

FAJARDO, R. Pluralismo jurídico y jurisdicción indígena en el horizonte del constitucionalismo pluralista. In: BALDI, Cesar Augusto (Coord.). Aprender desde o sul: novas constitucionalidades, pluralismo jurídico e plurinacionalidade. Belo Horizonte: Fórum, 2015. p. 35-57.

FAJARDO, R. Pluralismo jurídico, derecho indígena y jurisdicion especial en los países andinos. El otro Derecho, ISLA, Bogotá, n. 30, p. 171-193, jun. 2004. Available at: <https://www.cejamericas. org/Documentos/DocumentosIDRC/128elotrdr030-06.pdf>. Last access: 15 Dec. 2018. 
FERREIRA, A. O olhar do magistrado que presidiu o Tribunal do Júri Indígena. In: Conversa sobre Primeiro Tribunal do Júri na Terra Indígena Raposa Serra do Sol. Niterói: Universidade Federal Fluminense, Faculdade de Direito, Núcleo de Pesquisa sobre Práticas e Instituições Jurídicas (NUPIJ-UFF). Niterói: Universidade Federal Fluminense, 2016. Available at: <https://www.youtube. com/watch?v=8UP2XOsfi20>. Last access: 5 Jan. 2019.

FERREIRA, I.; POLACHINI, B.; ABÍLIO, A. A competência do Tribunal do Júri para julgar os crimes cometidos por indígenas. Revista Fafibe On-line, v. 9, n. 1, p. 88-102, dez. 2016. Available at: <http:// unifafibe.com.br/revistasonline/arquivos/revistafafibeonline/sumario/49/16032017212600.pdf>. Last access: 26 Dec. 2018.

COSTA, E. Júri indígena em Roraima absolve réu de tentativa de homicídio. Roraima, 2015. Available at: <http://g1.globo.com/rr/roraima/noticia/2015/04/juri-indigena-absolve-reu-de-tentativa-de-homicidio-e-condena-outro-em-rr.html> Last access: 19 Aug. 2019.

GABRIEL, O. Roraima realiza julgamento com primeiro júri popular indígena do País. Available at: <http://radioagencianacional.ebc.com.br/geral/audio/2015-04/roraima-realiza-julgamento-com-primeiro-juri-popular-indigena-do-pais\#player-radioagencia-nacional>. Last access: 19 Aug. 2019.

GARGARELLA, R. La sala de máquinas de la Consituición: dos siglos de constitucionalismo en América Latina (1810-2010). Buenos Aires: Katz Editores, 2014.

GOMES, M. Os índios e o Brasil. São Paulo: Contexto, 2012.

HOGEMANN, E. Constituição, Direitos Humanos e Pluralismo Jurídico: a possibilidade de controle à jurisdição indígena no Brasil a partir da comparação com a Constituição equatoriana. Revista Brasileira de Teoria Constitucional. Salvador, v. 4, n. 1, p. 114-129 jan./jun. 2018. Available at: <http://www.indexlaw.org/index.php/teoriaconstitucional/article/view/4408>. Last access: 5 Jan. 2019.

LACERDA, R. Os povos indígenas e a Constituinte: 1987 - 1988. Brasília: Conselho Indigenista Missionário, 2008.

LOBÃO, R. I Júri Popular Indígena realizado no Brasil. In: Seminário do Laboratório de Estudos da Cidadania, Administração de Conflito e Justiça do Departamento de Antropologia da Universidade de Brasília (CAJU-UnB). Brasília: Universidade de Brasília, 2015. Available at: <https://www.youtube.com/watch?v=oYRkFl5OhSw>. Last access: 10 Jan. 2019.

MACUXI, J. O olhar de uma das lideranças indígenas. In: Conversa sobre Primeiro Tribunal do Júri na Terra Indígena Raposa Serra do Sol. Niterói: Universidade Federal Fluminense, Faculdade de Direito, Núcleo de Pesquisa sobre Práticas e Instituições Jurídicas (NUPIJ-UFF). Niterói: Universidade Federal Fluminense, 2016. Available at: <https://www.youtube.com/watch?v=8UP2XOsfj20>. Last access: 11 Jan. 2019. 
MARQUES, É. Conhecendo o Malocão. Available at: <http://valoreseidentidademacuxi.blogspot. com/2014/01/conhecendo-o-malocao.html>. Last access: 31 Mar. 2019.

RAMOS, A. Os direitos do índio no Brasil: na encruzilhada da cidadania. Série Antropologia. vol. 116, Brasília: DAN/UnB, 1992. Available at: <http://dan.unb.br/images/doc/Serie116empdf.pdf>.

SILVEIRA, E. O olhar de um membro do Ministério Público. In: Conversa sobre Primeiro Tribunal do Júri na Terra Indígena Raposa Serra do Sol. Niterói: Universidade Federal Fluminense, Faculdade de Direito, Núcleo de Pesquisa sobre Práticas e Instituições Jurídicas (NUPIJ-UFF). Niterói: Universidade Federal Fluminense, 2016. Available at: <https://www.youtube.com/ watch?v=8UP2XOsfi20 >. Last access: 8 Jan. 2019.

UNIVERSIDADE ESTADUAL DE RORAIMA. Roraima tem primeiro júri popular indígena. Available at: <https://www.uerr.edu.br/roraima-tem-primeiro-juri-popular-indigena/>. Last access: 20 Mar. 2019.

VENEZUELA. Constituición de la República Bolivariana de Venezuela. Available at: <https:// www.oas.org/juridico/mla/sp/ven/sp_ven-int-const.html>. Last access: 8 Jan. 2019.

WOLKMER, A. Pluralismo Jurídico: fundamentos de uma nova cultura no Direito. 5. ed. São Paulo: Saraiva, 2015.

WOLKMER, A.; RONCHI, M.L. Processos constituintes latino-americanos e a presença dos movimentos sociais no Brasil e na Bolívia. Revista Culturas Jurídicas, v. 3, n. 6, p. 151-171. 2016. Available at: <http://www.culturasjuridicas.uff.br/index.php/rcj/article/view/187/94>.MENDES, Conrado Hübner. Una división de poderes deliberativa: entre el diálogo y la última palabra. In: 